University of Nebraska - Lincoln

DigitalCommons@University of Nebraska - Lincoln

Faculty Publications from the Harold W. Manter Laboratory of Parasitology

$6-2005$

Urotrema shirleyae n. sp. (Trematoda: Digenea: Urotrematidae) in Norops oxylophus and $N$. cupreus (Squamata: Iguania: Polychrotidae) from the Área de Conservación Guanacaste, Costa Rica

\author{
David Zamparo \\ University of Toronto \\ Daniel R. Brooks \\ University of Toronto,dnlbrooks@gmail.com \\ Vasyl Tkach \\ University of North Dakota
}

Follow this and additional works at: https://digitalcommons.unl.edu/parasitologyfacpubs

Part of the Parasitology Commons

Zamparo, David; Brooks, Daniel R.; and Tkach, Vasyl, "Urotrema shirleyae n. sp. (Trematoda: Digenea: Urotrematidae) in Norops oxylophus and N. cupreus (Squamata: Iguania: Polychrotidae) from the Área de Conservación Guanacaste, Costa Rica" (2005). Faculty Publications from the Harold W. Manter Laboratory of Parasitology. 249.

https://digitalcommons.unl.edu/parasitologyfacpubs/249

This Article is brought to you for free and open access by the Parasitology, Harold W. Manter Laboratory of at DigitalCommons@University of Nebraska - Lincoln. It has been accepted for inclusion in Faculty Publications from the Harold W. Manter Laboratory of Parasitology by an authorized administrator of DigitalCommons@University of Nebraska - Lincoln. 


\title{
UROTREMA SHIRLEYAE N. SP. (TREMATODA: DIGENEA: UROTREMATIDAE) IN NOROPS OXYLOPHUS AND N. CUPREUS (SQUAMATA: IGUANIA: POLYCHROTIDAE) FROM THE AREA DE CONSERVACIÓN GUANACASTE, COSTA RICA
}

\author{
David Zamparo, Daniel R. Brooks, and Vasyl Tkach* \\ Department of Zoology, University of Toronto, Toronto, Ontario, M5S 3G5 Canada. email: zamparo@zoo.utoronto.ca
}

\begin{abstract}
A new species of Urotrema inhabits Norops oxylophus and Norops cupreus from the Area de Conservación Guanacaste, Costa Rica. The new species is most similar to Urotrema scabridum but differs by having a relatively longer esophagus, at least $10 \%$ of the total body length versus $4-8 \%$ in $U$. scabridum; an oral sucker width: ventral sucker width ratio less than $1: 1$ (averaging $1: 0.76$ ) versus $1: 1$ or greater; an oral sucker width:pharyngeal width ratio less than $1: 0.5$ (averaging $1: 0.42$ ) versus greater than $1: 0.5$; and by having many transversely oriented posttesticular uterine loops versus a few vertically oriented posttesticular uterine loops.
\end{abstract}

The plagiorchioid Urotrematidae Poche, 1926, comprises Urotrema Braun, 1900, with 7 nominal species, and the monotypic Urotrematulum Macy, 1933, all of which inhabit mammals and lizards in the Nearctic and Neotropics. Bray et al. (1999) placed 2 additional genera, Sinineobucephalopsis Zhang, Pan \& Li, 1987, and Sinogastromyzontrema Li, Zhang \& Li, 1988, within the family. In a recent phylogenetic systematic analysis of the Bucephalidae, however, Overstreet and Curran (2002) supported the original authors' hypothesis that Sinineobucephalopsis and Sinogastromyzontrema are more closely related to members of the Bucephalidae than to Urotrematidae.

The taxonomic status of members of Urotrema is uncertain. Caballero (1942) recognized only 2 of the 5 nominal species of Urotrema known at that time, Urotrema scabridum Braun, 1900, inhabiting mammals, and Urotrema wardi, Perez-Vigueras, 1940, inhabiting lizards. In doing so, he synonymized Urotrema shillingeri Price, 1931, in a muskrat, Odatra zibthica, from Maryland, Urotrema lasiurensis, Alicata, 1932, in the bats Nycteris borealis and Nucteris humeralis from Texas and Maryland, respectively, and Urotrema minuta, Macy, 1933, in the bat Lasionycteris noctivagans from Minnesota. Penner (1941) had previously considered the latter 2 species synonyms of Urotrema schillingeri. Caballero and Grocott (1960) synonymized Urotrema aelleni Baer, 1957, in Myotis b. bocagei from the Ivory Coast, with Urotrema scabridum. Finally, Bray et al. (1999) treated Urotrema macrotestis Mane-Garzon \& Telias, 1965, in the water rat, Holochilus brasiliensis vulpinus, from Uruguay as part of what they termed the " $U$. scabridum complex."

Urotrema scabridum recently has been reported in a number of polychrotid lizards (anoles) from various localities in the Caribbean and Central America: Anolis olssoni from Hispaniola, West Indies (Goldberg et al., 1998); Anolis brevirostris from the Dominican Republic (Goldberg et al., 1996); Anolis sagrei from Andros Island, Bahamas, and San Salvador (Goldberg et al., 1994); and Anolis biporcatus (= Norops biporcatus) from Aquacate, Panama Province, Panama (Bursey et al., 2003). As part of the ongoing inventory of eukaryotic parasites of vertebrates of the Area de Conservación Guanacaste, Costa Rica, we have discovered numerous specimens of a species of Urotrema inhabiting 2 species of polychrotid lizards. We de-

Received 30 October 2003; revised 26 January 2004; accepted 26 January 2004.

* Department of Biology, University of North Dakota-Grand Forks, P.O. Box 9019, Grand Forks, North Dakota 58202-9019. scribe this species as new herein and briefly discuss the status of members of the $U$. scabridum complex.

\section{MATERIALS AND METHODS}

Worms were collected alive from recently killed hosts, killed, and fixed by shaking in hot formalin, then stored in $70 \%$ ethanol. Specimens were stained with Mayer's hematoxylin, dehydrated, and mounted in Canada balsam. The first series of values given are the range, with the mean value in parentheses. All measurements are in micrometers unless otherwise stated. All figures were made with the aid of a drawing tube. The following abbreviations for collections are used: CNHE, Colección Nacional de Helmintos, Instituto de Biología, Universidad Nacional Autónoma de Mexico; USNPC, United States National Parasite Collection, Beltsville, Maryland. Information concerning host identifications by specialists, digital images of hosts, and the disposition of host specimens and tissues is available via accessing http://brooksweb.zoo.utoronto.ca/ index.html.

\section{DESCRIPTION}

Urotrema shirleyae n. sp.

(Figs. 1-3)

Description (based on 94 specimens, 85 measured): Body elongate (Fig. 1), total body length (TBL) $0.93-4.8 \mathrm{~mm}(2.97 \mathrm{~mm})$ by $160-550$ (411) wide; maximum width at level of the ventral sucker. Tegument spined, very densely from the anterior end to level of the ovary; spines up to 10 long and 5 wide at base. Oral sucker subterminal 100-200 (153) long by $115-215$ wide (170). Pharynx 40-90 (66) long by 3895 (70) wide. Small glands free in the parenchyma surrounding the pharynx. Ratio of oral sucker width to pharyngeal width $1: 0.30-0.46$ (1:0.42). Prepharynx very short. Esophagus 190-500 (343) long, 10$20 \%(12 \%)$ of TBL. Intestine bifurcating 16-35\% (19\%) TBL from the anterior end. Posterior extent of ceca $15-24 \%$ (19\%) of TBL from the posterior end. Forebody $18-32 \%(22 \%)$ of TBL from the anterior end. Ventral sucker 80-200 (130) long by 90-190 (130) wide. Ratio of oral sucker width : ventral sucker width $1: 0.65-0.91(1: 0.76)$. Testes tandem; posterior testis $23-45 \%(29 \%)$ TBL from posterior end of body; anterior testis 95-310 (214) long by 110-335 (209) wide, posterior testis 112-300 (234) long by 93-305 (220) wide. Vasa efferencia may be inflated giving appearance of lobed testes. Vas deferens extending posteriorly from testes, ventromedially between ceca, entering cirrus sac proximally. Cirrus sac 100-325 (214) long by 30-100 (70) wide, width as percentage of length $33 \%(26-44 \%)$, containing coiled seminal vesicle filling most of the cirrus sac, terminal portion of the seminal vesicle extending anteriorly on dextral side, looping dorsally immediately anterior cirrus; cirrus poorly developed; pars prostatica weakly developed, with few prostatic cells present surrounding junction of ejaculatory duct and cirrus (Fig. 2). Genital pore subterminal, opening ventrally. Ovary spherical to subspherical, anterior to testes, 30\% (26-38\%) TBL from anterior end. Ovary 65-195 (134) long by 60-185 (129) wide. Ootype immediately posterior to ovary. Mehlis' gland present, Laurer's canal not observed. Seminal receptacle present, dorsal to Mehlis' gland (Fig. 3). Uterus intercecal, extending posteriad from ootype 


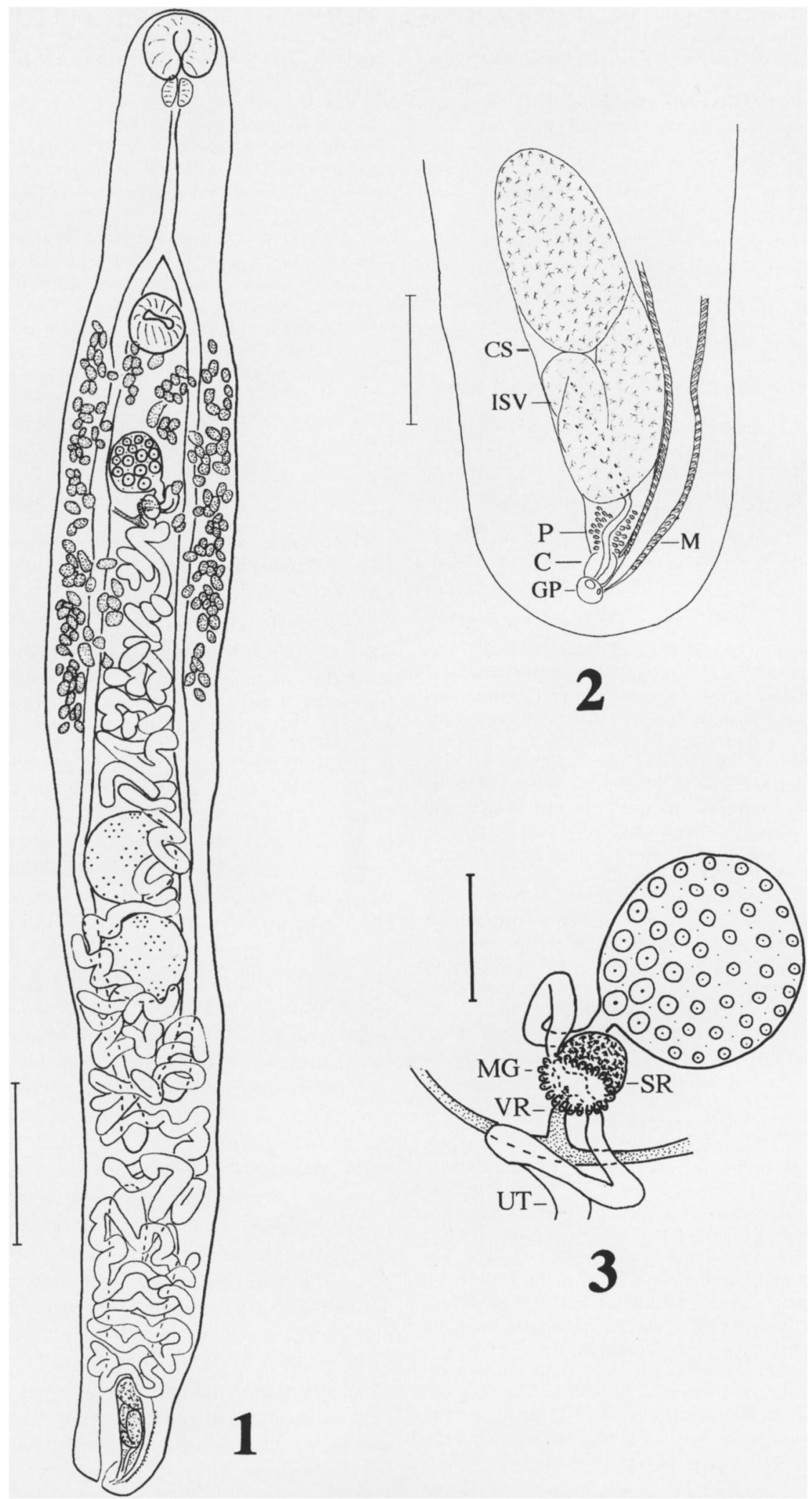

Figures 1-3. Urotrema shirleyae n. sp. 1. Ventral view of holotype. Scale bar $=500 \mu \mathrm{m}$. 2. Terminal genitalia. C $=$ cirrus; CS $=$ cirrus sac; $\mathrm{GP}=$ genital pore; $\mathbf{I S V}=$ internal seminal vesicle; $M=$ metraterm; $\mathrm{P}=$ prostatic cells. Scale bar $=100 \mu \mathrm{m}$. 3. Ootype region. $\mathrm{MG}=\mathrm{Mehlis}$ ' gland; $\mathrm{SR}=$ seminal receptacle; $\mathrm{UT}=$ uterus; $\mathrm{VR}=$ vitelline reservoir. Scale bar $=100 \mu \mathrm{m}$. 
in tight transverse coils, descending to genital pore. Metraterm weakly developed, similar in length to cirrus sac. Eggs 21-25 (22) long by 1011 (10) wide. Vitelline follicles in 2 lateral fields wrapped around ceca, both inter- and extracecal, several clusters of vitelline glands dorsally situated between ventral sucker and ovary (present in $84 \%$ of specimens); vitelline follicles extending anteriorly to ventral sucker, 19-28\% (24\%) TBL from the anterior end of the worm; posteriorly to anterior margin of anterior testis; total extent of vitelline fields $23-37$ (30\%) of TBL; follicles $37.5-47.5$ long by $22.5-32.5$ wide. Excretory pore, subterminal, opening dorsally. Excretory vesicle V-shaped.

\section{Taxonomic summary}

Type host: Norops oxylophus Cope, 1875 (Squamata: Iguania: Polychrotidae).

Other hosts: Norops cupreus Hallowell, 1860 (Squamata: Iguania: Polychrotidae).

Prevalence; intensity; site of infection: Thirty-eight percent (9/24); 21(4-39); small intestine.

Type locality: Rio Negro, near Buenos Aires, Sector Caribe, Area de Conservación Guanacaste, Guanacaste Province, Costa Rica $\left(32^{\circ} 05.72^{\prime} \mathrm{N}, 39^{\circ} 37.70^{\prime} \mathrm{W}\right)$.

Type material: Holotype: USNPC 94426. Paratypes: USNPC 9442794430.

Etymology: The species is named after Shirley Johansen.

\section{Remarks}

Specimens of the new species belong in Urotrema by having the terminal genitalia at the posterior end of the body, tandem testes near the posterior end of the hindbody, an ovary in the anterior hindbody separated from the testes by an extensive uterus, unlobed gonads, and vitelline follicles extending anteriorly to, or anterior to, the level of the ventral sucker. By having ceca that extend posterior to the posterior testis and vitelline follicles that do not extend anteriad to the level of the posterior margin of the pharynx, the new species is more similar to members of the $U$. scabridum complex than to $U$. wardi, which also inhabits anoles. Urotrema shirleyae differs from all nominal species assigned to the $U$. scabridum complex by having a relatively longer esophagus, at least $10 \% \mathrm{TBL}$ versus $4-8 \% \mathrm{TBL}$, and a relatively greater oral sucker width, with subsequently smaller oral sucker: pharynx width ratio $(1: 0.3-0.47,1: 0.42$ vs. $\geq 1: 0.5)$ and oral sucker: ventral sucker width ratio $(1: 0.6-0.8,1: 0.76$ vs. $\geq 1: 1)$. Finally, specimens attributed to U. scabridum from both chiropterans and lizards, including Braun's (1900) original description, have a few vertically oriented uterine loops extending from the sinistral side to the dextral side before crossing the body once again to the metraterm. Urotrema shirleyae, by contrast, exhibits many transversely oriented uterine loops between the posterior testis and the cirrus sac.

Most previous reports of Urotrema (Braun, 1900; Meyer and Reilly, 1950; Caballero et al., 1957; Mane-Garzon and Telias, 1965; Ubelaker, 1966; Nickel and Hansen, 1967; Webster, 1971; Martin, 1976; Coggins et al., 1981, 1982; Sellers, 1971; Sellers and Graham, 1987; Goldberg et al., 1994; Foster and Mertins, 1996; Goldberg et al., 1998; GuzmanCarnejo et al., 2003) have been from few, or individual, specimens, which seems to have led many to believe that there is a great deal of intraspecific variation in a few key characters examined. To test this hypothesis, we regressed all meristic characters listed in the description for 85 specimens of $U$. shirelyae against total body length (Fig. 4). All traits scaled positively and linearly with total body length, reducing variability in the measures. Figure 4 also includes regressed measures for specimens representing other members of the $U$. scabridum complex: $U$. aelleni (holotype from the University of Neuchatel), $U$. schillingeri (USNPC 29725); U. lasiurensis (USNPC 30118); U. minuta (USNPC 29953) and various specimens of $U$. scabridum (CNHE 215214; USNPC 51862; 78833; 79345; 80119;80120;80121;83851; 92189).

Specimens currently assigned to $U$. scabridum show great variation in a number of characters. This result is not surprising if $U$. scabridum is a composite of a number of different species, as suggested by Bray et al. (1999). Nonetheless, small sample sizes preclude any further evaluation of the complex. We are able, however, to demonstrate that, based on 94 specimens collected from 2 host species in the same locality, all fixed and prepared in the same way, $U$. shirleyae represents a highly consistent morphotype that does not vary to the same degree as does the collection of specimens currently assigned to $U$. scabridum. Examination of a voucher specimen (USNPC 92189) reported as $U$. scabridum in Anolis biporcatus (= Norops biporcatus) from Aquacate, Panama Province, Panama, by Bursey et al. (2003) revealed many posttesticular transverse uterine loops, similar to $U$. shirleyae and differing from the other members of the $U$. scabridum complex. That specimen also resembles $U$. shirleyae in ratios of oral sucker width:pharynx width $(1: 0.5)$ and oral sucker width: ventral sucker width $(1: 0.93)$. It differs from $U$. shirleyae in having a wider body, 22\% TBL compared with $15-16 \%$ for comparable sized $U$. shirleyae, an ovary 220 long by 235 wide versus less than 195 in diameter, and an esophagus measuring 9\% TBL. The specimen, which was collected from previously preserved hosts, is contracted, and we believe this accounts for the differences between that specimen and ours. Based on the structure of the uterine loops and the oral sucker width: ventral sucker width and oral sucker width: pharyngeal width ratios, we conclude that $U$. scabridum of Bursey et al. (2003) is $U$. shirleyae. Norops biporcatus is thus a new host and Aquacate, Panama Province, Panama, is a new locality for $U$. shirleyae.

\section{DISCUSSION}

During the course of the inventory in the Area de Conservación Guanacaste (ACG) to date, we have examined 62 specimens of 9 species of nonpolychrotid lizards, namely Ameiva festiva, Basiliscius basiliscus, Cnemidophorus sp., Phyllodactylus sp., Sceloporus sp., Ctenosaura quinquecarinata, C. similis, and Iguana iguana. As well, we have examined 124 specimens of 9 species of Norops (= Anolis in older literature), namely Norops biporcatus, Norops capito, Norops carpenteri, Norops cupreus, Norops humilis, Norops limifrons, Norops oxylophus, Norops pachypsus, and Norops tropidolepis, and have found $U$. shirleyae only in $N$. oxylophus and $N$. cupreus. We have collected specimens of Urotrema shirleyae in several snakes from the ACG. This may indicate that $U$. shirleyae occasionally occurs in snakes as a result of predation on polychtorid lizards. At present, we do not have enough information about the biology of the snake hosts or a large enough sample size to determine if that suspicion is warranted. Consequently, we do not list those snakes as hosts for $U$. shirleyae.

Etheridge (1960) divided Anolis into alpha and beta groups based on osteological data. Combined osteological, karyological, and electrophoretic data suggest that members of the alpha group are paraphyletic, with a monophyletic beta (Norops) group arising from within that group (Guyer and Savage, 1986, 1992). Recently, Nicholson (2002) used ITS-1 nuclear DNA sequence data to produce 382 parsimony informative characters for the members of Norops. Phylogenetic analysis yielded 9 equally parsimonious trees with bootstrap values and decay indices indicating that many groupings are weakly supported. As a result, she did not propose formal recognition of the resultant clades. The consensus tree indicates that $N$. auratus is the basalmost member of the clade, followed by a split into 2 subgroups. Norops tropidolepis and $N$. pachypus, which we have sampled in Guanacaste, but which do not host $U$. shirleyae, are sister species in one of those subgroups. All other species of Norops we have examined belong to the other subgroup. Norops oxylophus and $N$. cupreus, which host $U$. shirelyae, belong to the most derived portion of this second subgroup, which is largely unresolved. Norops cupreus is a basal member of a derived clade within that largely unresolved group that also includes $N$. limifrons and $N$. humilis, which we have been examined and which have not been found to host $U$. shirleyae. It appears that 


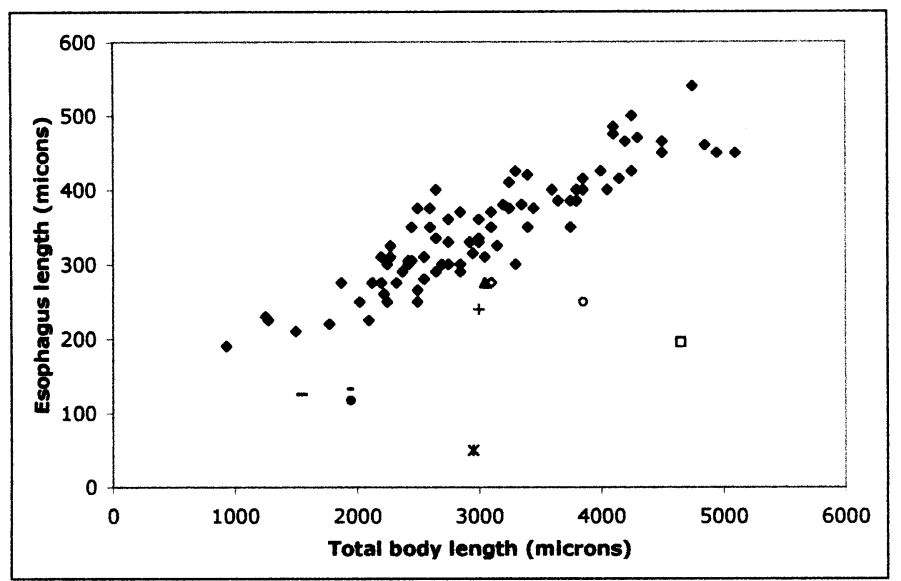

A

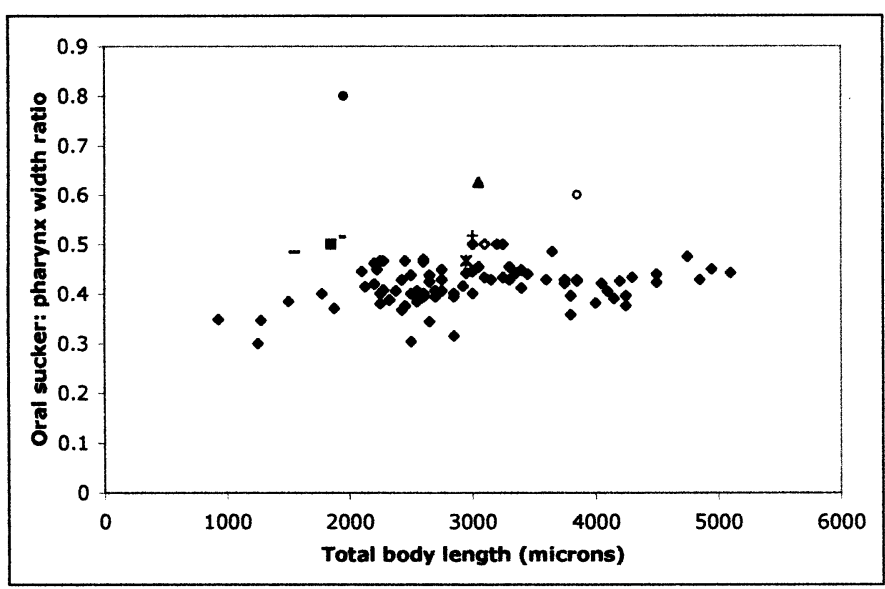

C

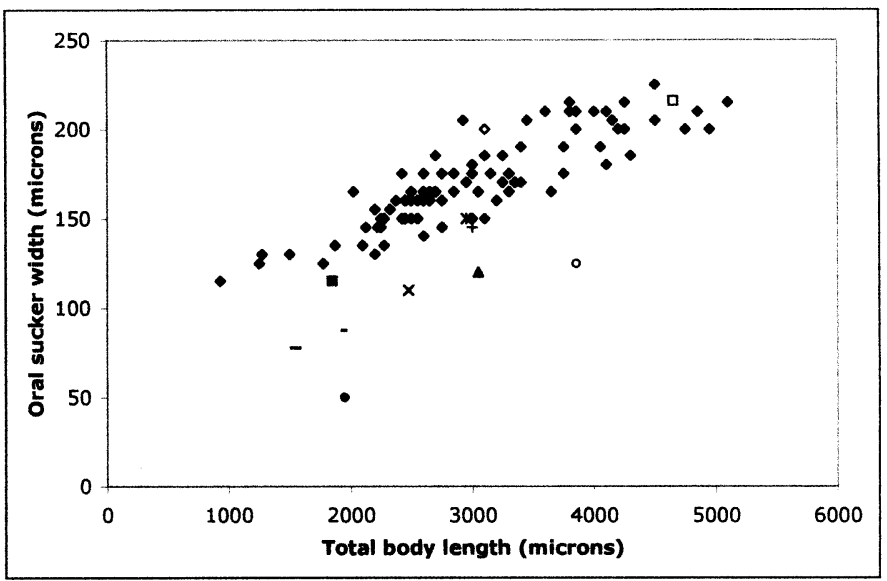

B

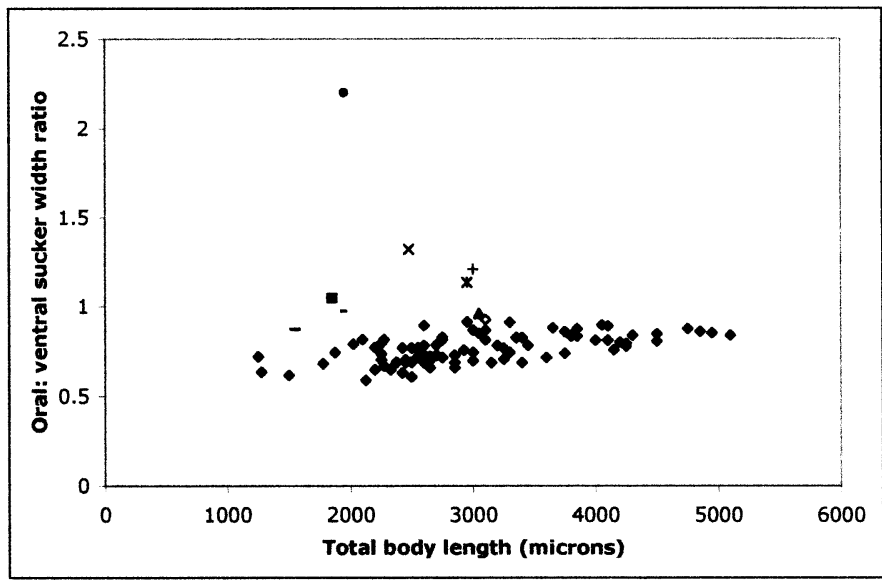

D

FIGURE 4. Regression analyses of Urotrema shirleyae n. sp. and members of the U. scabridum complex. A. Esophagus length plotted by total body length (TBL). B. Oral sucker width plotted by TBL. C. Oral sucker width pharynx width ratio plotted by TBL. D. Oral sucker width ventral sucker width ratio plotted by TBL. Units are in microns. Closed diamonds = Urotrema shirleyae; open diamond = USNPC-92189; closed square $=U$. aelleni (type); open square $=$ CNHE 214-215; closed circle $=$ USNPC-29953; open circle $=$ USNPC 83851; closed triangle $=$ USNPC 79345; short horizontal line $=$ USNPC 80120; long horizontal line $=$ USNPC 80121; X $=$ USNPC $29725 ;+=$ USNPC $51862 ; *=$ USNPC 30118.

$U$. shirleyae parasitizes only basal members from this derived group of anoles.

In contrast, Urotrema scabridum has only been reported from 1 species within the first subgroup of Norops, N. sagrei, from Florida and Louisiana (Sellers and Graham, 1987; Goldberg et al., 1994). All other reports of $U$. scabridum inhabiting anoles, Anolis armouri, Anolis barahonae, Anolis bahorucoensis, Anolis brevirostris, Anolis chlorocyanus, Anolis coelestinus, Anolis distichus, Anolis olssoni (Goldberg et al., 1994, 1996, 1998) and Anolis carolinesis (Sellers, 1971) have been from the paraphyletic alpha Anolis group.

\section{ACKNOWLEDGMENTS}

We are grateful to the scientific and technical staff of the ACG for support of this study, in particular, Elda Araya, Roger Blanco, Carolina Cano, Maria Marta Chavarría, Felipe Chavarría, Roberto Espinoza, Dunia Garcia, Guillermo Jimenez, Elba Lopez, Sigifredo Marin, Alejandro Masis, Calixto Moraga, Fredy Quesada, and Petrona Rios. Thanks also to Dan Janzen and Winnie Hallwachs, scientific advisers to the ACG, for their support. This study was funded by a research grant from the Natural Sciences and Engineering Research Council (NSERC) of Canada to D.R.B.

\section{LITERATURE CITED}

Bray, R. A., D. Gibson, And Z. Jianying. 1999. Urotrematidae Poche, 1926 (Platyhelminthes: Digenea) in Chinese freshwater fishes. Systematic Parasitology 44: 193-200.

Braun, M. 1900. Trematoden der Chiroptera. Annalen des Naturhistorieschen Hofmuseum Wien 15: 217-236.

Bursey, C. R., S. R. Goldberg, and S. R. Telford, JR. 2003. Strongyluris panamaensis $\mathrm{n}$. sp. (Nematoda: Heterakidae) and other helminths from the lizard, Anolis biporcatus (Sauria: Polychrotidae), from Panama. Journal of Parasitology 89: 118-123.

Caballero, C. E. 1942. Trematodos de los murcielagos de Mexico. III Descripcion de Urotrema scabridum Braun 1900, y posicion sistematica de las especies Norteamericanas de este genero. Anales del Instituto de Biologia 13: 641-648.

, R. R. BREnES, AND O. JimÉnEZ-Quirós. 1957. Helmintos de la República de Costa Rica IV. Algunos tremátodos de animales domesticos y silvestres. Revista de Biologia Tropical 5: 135-155. 
And R. G. Grocott. 1960. Helmintos de la República de Panamá. XXIII. Estudios de dos tremátodos de murciélagos, con descripción de una nueva especie. Ciencia 19: 244-248.

Coggins, J. R., J. L. Tedesco, And C. Rupprecht. 1981. Intestinal helminths of the bat, Myotis keenii (Merriam), from Southeastern Wisconsin. Proceedings of the Helminthological Society of Washington 48: $93-96$.

982. Seasonal changes and overwintering of parasites in the bat, Myotis lucifugus (Le Conte), in a Wisconsin Hibernaculum. American Midland Naturalist 107: 305-315.

ETHERIDGE, R. 1960. The relationships of the anoles (Reptilia: Sauria: Iguanidae): An interpretation based on skeletal morphology. Ph.D Dissertation. University of Michigan, Ann Arbor, Michigan, 249 p.

Foster, G. W., And J. W. Mertins. 1996. Parasitic helminths and arthropods from Brazilian free-tailed bats (Tadarida brasiliensis cy nocephala) in Florida. Journal of the Helminthological Society of Washington 63: 240-245.

Goldberg, S. R., C. R. Bursey, and H. Cheam. 1996. Gastrointestinal helminths of six anole species, Anolis armouri, A. barahonae, A bahorucoensis, A. brevirostris, A. chlorocyanus and A. coelestinus (Polychrotidae) from Hispaniola. Caribbean Journal of Science 32: $112-115$.

- -1, AND TAWIL. 1994. Helminth parasites of the bark anole, Anolis distichus and the brown anole, Anolis sagrei (Polychridae) from Florida and the Bahamas. Caribbean Journal of Science 30: $275-277$.

. AND 1998. Helminths of six species of Anolis lizards (Polychrotidae) from Hispaniola, West Indies. Journal of Parasitology 84: 1291-1295.

Guyer, C. AND J. M. SAvage. 1986. Cladistic relationships among anoles. Systematic Zoology 35: 509-531. , AND - 1992. Anole systematics revisited. Systematic Biology 41: 89-110.

Guzman-Carnejo, C., L. Garcia-Prieto, G. Perez-Ponce de Leon, And J. B. Orales-Malacara. 2003. Parasites of Tadarida brasiliensis mexicana (Chiroptera: Molossidae) from arid regions of Mexico. Comparative Parasitology 70: 11-25.
Mane-Garzon, F., and D. Telias. 1965. Un nuevo trematodo del genero Urotrema de la rata de agua y redescipcion de Urotrema scabridum Braun, 1900. Comunicaciones Zoologicas del Museo de Historia Natural de Montevideo 8: 1-9.

MARTIN, D. R. 1976. New host and distribution records of helminth parasites of the Mexican free-tail bat, Tararida brasiliensis, from Texas and Louisiana. Proceedings of the Helminthological Society of Washington 43: 85-86.

Meyer, M. C., AND J. R. Reilly. 1950. Parasites of muskrats in Maine. American Midland Naturalist 44: 467-477.

NichOLSON, K. E. 2002. Phylogenetic analysis and a test of the current infrageneric classification of Norops (Beta Anolis). Herpetological Monographs 16: $93-120$.

Nickel, P. A., AND M. F. HANSEN. 1967. Helminths of bats collected in Kansas, Nebraska and Oklahoma. American Midland Naturalist 78: 481-486.

Overstreet, R. M., And S. S. Curran. 2002. Superfamily Bucephaloidea Poche, 1907. In Keys to the Trematoda, D. I. Gibson, A. Jones, and R. A. Bray (eds.). CAB International and The Natural History Museum, London, U.K., p. 67-110.

PenNer, L. R. 1941. The status of Urotrema shillingeri Price, 1931 (Trematoda: Urotrematidae). Transactions of the American Microscopical Society 60: 359-364.

Price, E. W. 1931. Four new species of trematode worms from the muskrat, Ondatra zibethica, with a key to the trematode parasites of the muskrat. Proceedings of the United States National Museum 79: $1-13$.

SEllers, L. G. 1971. Three helminthes recovered from Anolis carolinesis. Journal of Parasitology 57: 355.

, AND G. GRAhAM. 1987. Trematodes of Cunban brown anoles, Anolis sagrei sagrei, from Florida. Proceedings of the Helminthological Society of Washington 54: 266-267.

Ubelaker, J. E. 1966. Parasites of the gray bat, Myotis grisecens, in Kansas. American Midland Naturalist 75: 199-204.

Webster, W. A. 1971. Studies on the parasites of Chiroptera. I. Helminths of Jamaican bats of the genera Tadarida, Chilonycteris, and Monophyllus. Proceedings of the Helminthological Society of Washington 38: 195-200. 